\title{
Impact of Annual Weather Fluctuations on Wine Production in Germany*
}

\begin{abstract}
Britta Niklas $^{\text {a }}$
Abstract

This paper analyzes the impact of annual weather fluctuations on the total output of wine and on the share of output of different wine-quality categories in Germany, using a set of wine data from all thirteen German wine regions and daily weather data taken from regional weather stations. The empirical analysis suggests that rising average temperatures have a significantly positive impact on the total output of wine as well as on the output shares of wine in higherquality categories. The number of freezing days appears to be detrimental to overall production; precipitation during the growing season impairs higher-quality wines in particular. (JEL Classifications: Q21, Q13)
\end{abstract}

Keywords: GLM, SUR model, weather fluctuations, wine production Germany, wine quality.

\section{Introduction and Research Question}

Changing climate, global warming, and weather fluctuations have a special importance for agricultural production. The relationship between weather and wine production is especially strong; therefore, fine wine has characteristics that make this connection an interesting topic for economic analysis (Ashenfelter and Storchmann, 2016). As German wine regions ${ }^{1}$ are situated near the northern boundary of commercial grape growing, stretching from the south $\left(47.32^{\circ} \mathrm{N}\right)$ to the north $\left(51.32^{\circ} \mathrm{N}\right)$ of Germany, wine producers depend highly on favorable weather conditions (Ashenfelter and Storchmann, 2010).

\footnotetext{
* I am indebted to an anonymous referee and participants at the 11th Annual AAWE Conference in Padua for many helpful comments.

${ }^{a}$ Institute of Development Research and Development Policy, Ruhr-University Bochum, Universitätsstr. 105, 44789 Bochum, Germany; e-mail: britta.niklas@rub.de.

${ }^{1}$ There are thirteen different wine regions in Germany. An area of about 102,000 hectares is used for grape growing, where about 18,700 enterprises produce about 9.3 million $\mathrm{hL}$ of wine (German Wine Institute, 2016).
}

(C) American Association of Wine Economists, 2018 
German wines are categorized by the degree of ripeness of the grapes, measured as the content of natural sugar in the must (grape juice) upon harvest; the German term is degree Oechsle. ${ }^{2}$ The higher the sugar level, the higher the wine will be categorized. The quality categories and responding Oechsle thresholds vary from region to region. For instance, in the region Pfalz (Palatinate), the quality levels fall into the following brackets: Qualitätswein (Qba) (60-72 ${ }^{\circ}$ Oechsle), Kabinett (73-84 Oechsle), Spätlese ( $85-91^{\circ}$ Oechsle), Auslese ( $92-119^{\circ}$ Oechsle), Beerenauslese and Eiswein $\left(120-149^{\circ}\right.$ Oechsle), and Trockenbeerenauslese ( $>150^{\circ}$ Oechsle). With the exception of Qualitätswein (Qba), ${ }^{3}$ it is illegal to add sugar to the must (Ashenfelter and Storchmann, 2010).

This paper examines to what extent weather and annual weather fluctuations affect the total wine production and the shares of different quality categories in Germany.

\section{Previous Literature}

A growing number of studies has examined the potential impact of weather variation and, as their long-run expression, climatic changes on wine quality, grape yields, and production levels. Ashenfelter and Storchmann (2016) provide a literature review of one wine and climate change. Measures of quality can be divided into direct and indirect measures. Direct measures rely on quantifiable wine characteristics, such as alcohol level or the sugar content of the must (degree Oechsle), while indirect measures refer to vintage scores, quality ratings from wine guides, expert ratings, or prices for rankings.

The research dealing with direct measures of quality shows contradictory results. Ashenfelter (2008) stresses that the quality of any fruit depends on weather during the growing season and that some regions have more- and less-pronounced weather fluctuations. High-quality vintages for Bordeaux wines, for example, correspond to years with a dry August and September, a warm growing season, and a wet previous winter. Storchmann (2005) suggests, in an analysis of the impact of weather on wine quality of Schloss Johannisberg for the years 1700 to 2003, that warming improves the quality of wine. Alston et al. (2011) find, for the years 1980-2005, that rising temperatures contribute to higher sugar levels of wine grapes in California, as Brix levels increased by an average of 0.23 percent annually. Alston et al. $(2011,2015)$ find that alcohol levels have increased in U.S. and Canadian

\footnotetext{
${ }^{2}$ Degree Oechsle denotes the specific weight of the must compared to the weight of water at a temperature of 20 degrees. One liter of water weighs $1,000 \mathrm{~g}$, which equals 0 degrees Oechsle. Grape must, with a mass of $1,084 \mathrm{~g}$ per liter, has 84 degrees Oechsle. The mass difference is almost entirely due to the dissolved sugar in the must, so that Oechsle measures the relative sweetness of the grape juice (Ashenfelter and Storchmann, 2010).

${ }^{3}$ Although their production levels are insignificant (less than $1 \%$ of total production), there are two categories below Qualitätswein (Qba): Tafelwein and Landwein.
} 
wineries due to higher Brix levels. Mira de Orduña (2010) finds that higher growingseason temperatures cause sweeter musts and stronger wines, but that extremely high temperatures may negatively affect wine aroma and color. Leeuwen and Darriet (2016) show that higher temperatures lead to higher quality levels in Languedoc during the years 1984 to 2013, but this tendency could change due to water deficits. Oczkowski (2016) identifies winners and losers of temperature changes, depending on the grape variety. This paper adds to this body of research by focusing on all thirteen German wine regions. I use the output (in hectoliters) of wine of different quality categories as a direct measure of quality, as these categories are directly related to the sugar content of the must.

Most of the above-mentioned literature applies hedonic approaches. These approaches all relate dependent variables to their visible characteristics or attributes, which are continuously measurable (quantitatively) or not (qualitatively) (Oczkowski, 1994). Authors often choose the average temperature and the total rainfall over the growing and winter season as weather variables (Ashenfelter and Storchmann, 2010), but this paper applies a hedonic approach using various average temperatures (during the whole, ${ }^{4}$ growing, and harvest seasons), the number of soil-freezing days during the growing and harvest seasons, and the total precipitation during the winter, growing, and harvest seasons (see Table 1).

\section{Data on Weather and Quality}

Because meso-weather data for the vineyard in which the grapes were grown are almost never available, most studies rely on weather data from nearby weather stations. This study draws on data from regional weather stations that are located within each of the thirteen German viticultural regions and cover the time period from 2003 to $2013 .^{5}$

Lecocq and Visser (2006) for Bordeaux and Haeger and Storchmann (2006) for California, respectively, show that within a homogenous wine region, local weather data yield little additional explanatory power over regionally aggregated weather data; but this paper refers to data from regional weather stations, as weather conditions in Germany differ significantly between regions. The German Wine Institute (2003-2016) provides data on the output of hectoliters per quality category and the share of output for Qualitätswein (Qba), the lowest-quality category;

\footnotetext{
${ }^{4}$ The whole season comprises winter (Dec. 1 to Feb. 28), growing (Mar. 1 to Sep 15.) and harvest (Sep 16. to Oct. 31) time. The growing phase nowadays already starts in March, while the majority of grapes are picked from the middle of September to the end of October (Fecke, 2014; Kriener and Mortsiefer, 2017). ${ }^{5}$ Regional weather data are from the following: Ahr: Bad Neuenahr-Ahrweiler - Baden: Karlsruhe/ Rheinstetten and Freiburg, Franken: Würzburg as closest station, Hessische Bergstraße: Mannheim Mittelrhein: Montabauer and Nastätten, Mosel: Bernkastel and Trier Petrisberg, Nahe: Bad Kreuznach, Pfalz: Bad Dürkheim, Rheingau: Geisenheim, Rheinhessen: Alzey, Saale-Unstrut: Osterfeld, Sachsen: Dresden-Hosterwitz, Württemberg: Sachsenheim.
} 
Table 1

Descriptive Statistics

\begin{tabular}{|c|c|c|c|c|c|}
\hline Variable & Obs. & Mean & Std. Dev. & Min. & Max. \\
\hline Production total $(\mathrm{hL})$ & 143 & $608,225.1$ & $708,085.6$ & 10,000 & $2,288,969$ \\
\hline $\mathrm{Qba}^{\mathrm{a}}$ total $(\mathrm{hL})$ & 143 & $525,052.7$ & $621,220.5$ & 7,600 & $1,918,662$ \\
\hline Kabinett total (hL) & 143 & $38,788.3$ & $38,837.9$ & 0 & 135,400 \\
\hline Spätlese total (hL) & 143 & $35,731.7$ & $59,128.8$ & 0 & 263,057 \\
\hline Auslese total (hL) & 143 & $7,176.45$ & $13,176.5$ & 0 & 68,616 \\
\hline Batbaice $^{\mathrm{b}}$ total $(\mathrm{hL})$ & 143 & 1476 & 3806.0 & 0 & 20,984 \\
\hline $\mathrm{Qba}^{\mathrm{a}}$ (share in \%) & 143 & 83.93 & 8.78 & 59.96 & 99.72 \\
\hline Kabinett (share in \%) & 143 & 8.56 & 6.83 & 0 & 31.23 \\
\hline Spätlese (share in \%) & 143 & 5.97 & 3.75 & 0 & 18.90 \\
\hline Auslese (share in \%) & 143 & 0.99 & 1.09 & 0 & 5.00 \\
\hline Batbaice $^{\mathrm{b}}$ (share in \%) & 143 & 0.11 & 0.18 & 0 & 0.96 \\
\hline Temperature min. (avg.) ${ }^{\mathrm{c}}$ & 143 & 7.83 & 0.62 & 6.42 & 9.32 \\
\hline Soil-freezing days ${ }^{\mathrm{d}}$ & 143 & 30.99 & 7.85 & 12 & 52 \\
\hline Temperature (avg.) ${ }^{\mathrm{c}}$ & 143 & 12.68 & 0.79 & 10.29 & 14.51 \\
\hline Temperature, growing season (avg.) $)^{\mathrm{e}}$ & 143 & 17.56 & 1.05 & 15.25 & 21.14 \\
\hline Temperature, harvest season (avg.) ${ }^{\mathrm{e}}$ & 143 & 10.39 & 1.18 & 7.76 & 13.78 \\
\hline Precipitation, winter season (sum) ${ }^{\mathrm{e}}$ & 143 & 140.77 & 48.63 & 66.2 & 396.8 \\
\hline Precipitation, growing season (sum) & 143 & 381.04 & 112.62 & 160.9 & 794.3 \\
\hline Precipitation, harvest season (sum) $)^{e}$ & 143 & 73.90 & 38.81 & 19.1 & 248.5 \\
\hline
\end{tabular}

${ }^{a}$ Qba: Qualitätswein. ${ }^{\mathrm{b}}$ Batbaice: Beerenauslese/Trockenbeerenauslese/Eiswein. ${ }^{\mathrm{c}}$ Temperature and temperature min.: avg. of the whole season (winter, growing, harvest). ${ }^{4}$ Soil-freezing days: sum of days with soil temperatures $<0$ degrees during the growing and harvest seasons. ${ }^{5}$ Winter season: Dec. 1 to Feb 28; Growing season: Mar. 1 to Sep 15; Harvest season: Sep. 16 to Oct. 31 .

Kabinett; Spätlese; and Auslese. For Beerenauslese (BA), Trockenbeerenauslese (TBA), and Eiswein (ICE), which are deemed the highest quality, only aggregated figures exist, here denoted as BA-TAB-ICE or "Batbaice." Descriptive statistics for the data are presented in Table 1.

\section{Methods and Results}

Suppose there are two wines, one of high quality $(\mathrm{H})$ and another of low quality $(\mathrm{L})$. The quantity produced in each segment, i.e., $\mathrm{Q}_{\mathrm{H}}$ and $\mathrm{Q}_{\mathrm{L}}$, depends on weather $(\mathrm{W})$ in two ways. First, beneficial weather, depicted by a high $\mathrm{W}$ value, has a positive impact on the yields of both wines. Second, T will also affect the likelihood of each wine's falling into the $\mathrm{L}$ or $\mathrm{H}$ bracket. That is, although conducive $\mathrm{W}$ conditions may directly boost the yield of $\mathrm{H}$ wine produced even at constant $\mathrm{L}$ and $\mathrm{H}$ shares, they also increase the likelihood of any given wine's falling into the $\mathrm{H}$ bracket. The overall effect in $\mathrm{H}$ wines is unambiguous, because both effects increase their quantity produced.

Therefore,

$$
Q_{H}(W)=f\left(Y_{H}(W), S_{H}(W)\right)
$$


The marginal effect of $\mathrm{T}$ on $\mathrm{Q}_{\mathrm{H}}$ is then

$$
Q_{H}(T)=\frac{\partial Y_{H}}{\partial W} \frac{\partial Q_{H}}{\partial Y_{H}}+\frac{\partial S_{H}}{\partial W} \frac{\partial Q_{H}}{\partial S_{H}} .
$$

Likewise, $\mathrm{Q}_{\mathrm{L}}$ equals

$$
Q_{L}(T)=\frac{\partial Y_{L}}{\partial W} \frac{\partial Q_{L}}{\partial Y_{L}}+\frac{\partial S_{L}}{\partial W} \frac{\partial Q_{L}}{\partial S_{L}} .
$$

Yield-wise, $\mathrm{W}$ is assumed to have positive marginal effect for both wines, i.e.,

$$
\frac{\partial Y_{H}}{\partial W}>0 \text { and } \frac{\partial Y_{L}}{\partial W}>0 .
$$

Share-wise, however, the effects are different:

$$
\frac{\partial S_{H}}{\partial W}>0 \text { and } \frac{\partial S_{L}}{\partial W}<0 .
$$

That is, the overall effect of beneficial weather on the quantity of lower-quality wine produced is supposed to be ambiguous.

Empirically, I estimate the impact of weather first on total production and then on production shares in each of the five quality categories by applying a standard panel data model with the thirteen wine regions for the time period of 2003 to 2013.

I estimate equation (1) with the logarithm of the total production as dependent variable $y$, regional fixed effects, and cluster robust standard errors:

$$
\ln \mathrm{y}_{\mathrm{it}}=\beta^{\prime} \mathrm{w}_{\mathrm{it}}+\mathrm{u}_{\mathrm{it}}, \quad i=1, \ldots, 13 ; t=1, \ldots, 11 ; u_{i t}=\alpha_{i}+v_{i t},
$$

where $w_{\mathrm{it}}$ is a $\mathrm{k}^{*} 1$ vector of weather variables and $\beta$ is a $\mathrm{k}^{*} 1$ vector of parameters to be estimated. The error term $u_{\mathrm{it}}$ consists of a time-invariant individual-specific unobserved effect $\alpha_{i}$ and the idiosyncratic error term $v_{\text {it }}$ (e.g., Hoyos and Sarafidis, 2006). Table 2 shows the results.

The results suggest a significantly positive impact of average growing-season temperatures on production, whereas additional soil-freezing days appear to exert a negative effect.

When analyzing the impact of weather on the share of production, the following problem arises due to the categories' interdependent dependence: an increase in the share of one category implies a decrease somewhere else. As a result, the error terms are correlated across equations. In this case, it seems appropriate to employ Zellner's (1962) Seemingly Unrelated Regression (SUR), which allows for jointly estimating a system of equations with exogenous predictors. Zellner bases his approach on constructing a stepwise algorithm using first the Generalized Least Squares (GLS) approach for the estimation of each individual-specific equation and then using the Maximum Likelihood approach for estimating the residual covariance matrix (Sarafidis and Wansbeek, 2012). Table 3 reports the results of the SUR approach. 
Table 2

Regional Fixed-Effects Estimation on Total Production

\begin{tabular}{|c|c|c|c|}
\hline & In production (1) & In production (2) & In production (3) \\
\hline Temperature, growing season (avg.) $)^{1}$ & $\begin{array}{l}0.0302^{* *} \\
(2.66)\end{array}$ & $\begin{array}{l}0.428^{*} \\
(2.29)\end{array}$ & $\begin{array}{l}0.0263^{*} \\
(2.23)\end{array}$ \\
\hline Temperature, harvest season (avg.) ${ }^{1}$ & $\begin{array}{l}-0.00544 \\
(-0.76)\end{array}$ & $\begin{array}{l}-0.00198 \\
(-0.27)\end{array}$ & \\
\hline Temperature, min. (avg. whole season) ${ }^{1}$ & & & $\begin{array}{l}0.0196 \\
(0.99)\end{array}$ \\
\hline Soil-freezing days ${ }^{2}$ & $\begin{array}{l}-0.00526^{* * *} \\
(-3.95)\end{array}$ & & $\begin{array}{l}-0.00440 * * \\
(-3.18)\end{array}$ \\
\hline Precipitation, growing season (sum) ${ }^{1}$ & $\begin{array}{l}0.000157 \\
(1.24)\end{array}$ & $\begin{array}{l}0.000136 \\
(1.03)\end{array}$ & $\begin{array}{l}0.000159 \\
(1.22)\end{array}$ \\
\hline $\begin{array}{l}\text { Precipitation, harvest season (sum) }{ }^{1} \\
\left(\text { Temperature, growing season }(\mathrm{avg.})^{1}\right)^{2}\end{array}$ & $\begin{array}{l}-0.000120 \\
(-0.40)\end{array}$ & $\begin{array}{l}-0.000241 \\
(-0.78) \\
-0.0113^{*} \\
(-2.20)\end{array}$ & $\begin{array}{l}-0.000167 \\
(-0.64)\end{array}$ \\
\hline Constant & $\begin{array}{l}10.13^{* * *} \\
(44.89)\end{array}$ & $\begin{array}{l}6.423^{* * *} \\
(3.84)\end{array}$ & $\begin{array}{l}9.978^{* * * *} \\
(42.82)\end{array}$ \\
\hline$N$ & 143 & 143 & 143 \\
\hline$R^{2}$ & 0.997 & 0.997 & 0.997 \\
\hline Adj. $R^{2}$ & 0.997 & 0.997 & 0.997 \\
\hline
\end{tabular}

Robust $t$ statistics are in parentheses; significance levels are ${ }^{*} p<0.05, * * p<0.01$, and $* * * p<0.001 .{ }^{1}$ Winter season: Dec. 1 to Feb. 28 ; growing season: Mar. 1 to Sep. 15 ; harvest season: Sep. 16 to Oct. $31 .{ }^{2}$ Soil-freezing days: sum of days with soil temperatures $<0$ degrees during the growing and harvest seasons.

As expected, temperature's positive impact on the respective shares increases with increasing quality level. That is, the warmer the growing season, the more likely a certain wine will be classified in a superior quality bracket. In contrast, rainfall appears to have no consistent and significant effect on the quality share distribution. This may be due to the local character of precipitation, i.e., the weather station some $20 \mathrm{~km}$ away from the vineyard may record some rain while the vineyard has been dry, and vice versa.

The SUR model may not be the perfect way to approach a regression where the explained variables vary within a $0-1$ boundary, as SUR may predict share values that are outside this range. I, therefore, also used a generalized linear model (GLM) that allows predicted values to only fall within the $0-1$ boundary. The result is the same as for equation (1), but now with the share of production as a dependent variable (UCLA, 2017). I also added various additional interaction terms as independent variables; Qualitätswein (Qba) is the reference category. Table 4 shows the results of this estimation.

Similar to the SUR results, the GLM panel results suggest an increasingly positive impact of temperature with higher qualities. However, the temperature effects on the highest category, Batbaice (Beerensauslese-Trockenbeerenauslese-Eiswein), are not 
Table 3

Results of the SUR Model for Shares of Production

\begin{tabular}{|c|c|c|c|c|c|}
\hline & $Q b a^{b}$ & Kabinett & Spätlese & Auslese & Batbaice $^{c}$ \\
\hline Temperature min. (avg. whole season) ${ }^{\mathrm{a}}$ & $\begin{array}{c}0.531 \\
(1.36)\end{array}$ & $\begin{array}{l}-0.107 \\
(-0.57)\end{array}$ & $\begin{array}{l}0.337^{*} \\
(2.39)\end{array}$ & $\begin{array}{l}0.416^{* * *} \\
(8.74)\end{array}$ & $\begin{array}{l}0.0825^{* * * *} \\
(12.14)\end{array}$ \\
\hline Precipitation Winter season $(\mathrm{sum})^{\mathrm{a}}$ & $\begin{array}{l}-0.00243 \\
(-0.29)\end{array}$ & $\begin{array}{l}0.00273 \\
(0.73)\end{array}$ & $\begin{array}{l}-0.00294 \\
(-0.77)\end{array}$ & $\begin{array}{l}0.00307^{*} \\
(1.97)\end{array}$ & $\begin{array}{l}0.0000300 \\
(0.16)\end{array}$ \\
\hline Precipitation Growing season (sum) ${ }^{\mathrm{a}}$ & $\begin{array}{l}0.00782 * \\
(2.11)\end{array}$ & $\begin{array}{l}0.000946 \\
(0.57)\end{array}$ & $\begin{array}{l}-0.00390 * \\
(-2.23)\end{array}$ & $\begin{array}{l}-0.000963 \\
(-1.34)\end{array}$ & $\begin{array}{l}-0.000172 \\
(-1.72)\end{array}$ \\
\hline$N$ & 143 & & & & \\
\hline
\end{tabular}

$t$ statistics are in parentheses; significance levels are ${ }^{*} p<0.05,{ }^{* *} p<0.01$, and ${ }^{* * *} p<0.00 .{ }^{a}$ Winter season: Dec. 1 to Feb. 28 ; growing season: Mar. 1 to Sep. 15 ; harvest season: Sep. 16 to Oct. $31 .{ }^{b}$ Qualitätswein (Qba). ${ }^{\mathrm{c}}$ Batbaice: Beerenauslese/Trockenbeerenauslese/Eiswein. 
Table 4

Results of the GLM Approach for Shares of Production

\begin{tabular}{|c|c|c|c|}
\hline & $\begin{array}{c}\text { Share } \\
\text { production }\end{array}$ & & $\begin{array}{c}\text { Share } \\
\text { production }\end{array}$ \\
\hline $\begin{array}{l}\text { Temperature } \\
\text { (avg. whole season) }^{\mathrm{a}}\end{array}$ & $\begin{array}{l}-0.145 \\
(-1.64)\end{array}$ & $\begin{array}{l}\text { Precipitation, winter } \\
\text { season*Kabinett }\end{array}$ & $\begin{array}{l}0.0026 \\
(1.43)\end{array}$ \\
\hline $\begin{array}{l}\text { Precipitation, winter season } \\
\quad(\text { sum })^{\mathrm{a}}\end{array}$ & $\begin{array}{c}-0.00128 \\
(-0.98)\end{array}$ & $\begin{array}{l}\text { Precipitation, winter } \\
\text { season*Spätlese }\end{array}$ & $\begin{array}{l}0.0014 \\
(0.90)\end{array}$ \\
\hline 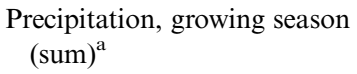 & $\begin{array}{l}0.0016^{* *} \\
(2.64)\end{array}$ & $\begin{array}{l}\text { Precipitation, winter } \\
\text { season*Auslese }\end{array}$ & $\begin{array}{l}0.0041 \\
(1.81)\end{array}$ \\
\hline Temperature*Kabinett & $\begin{array}{l}0.315^{* *} \\
(3.03)\end{array}$ & $\begin{array}{l}\text { Precipitation, winter } \\
\text { season*Batbaice }{ }^{2}\end{array}$ & $\begin{array}{l}-0.0048 \\
(-1.28)\end{array}$ \\
\hline Temperature*Spätlese & $\begin{array}{l}0.232^{* *} \\
(2.65)\end{array}$ & $\begin{array}{l}\text { Precipitation, growing } \\
\text { season*Kabinett }\end{array}$ & $\begin{array}{l}-0.0020^{*} \\
(-2.50)\end{array}$ \\
\hline Temperature*Auslese & $\begin{array}{l}0.293^{* *} \\
(2.44)\end{array}$ & $\begin{array}{l}\text { Precipitation, growing } \\
\text { season*Spätlese }\end{array}$ & $\begin{array}{l}-0.0036^{* * *} \\
\quad(-5.50)\end{array}$ \\
\hline 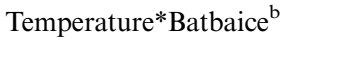 & $\begin{array}{l}0.0750 \\
(0.43)\end{array}$ & $\begin{array}{l}\text { Precipitation, growing } \\
\text { season*Auslese }\end{array}$ & $\begin{array}{l}-0.0042^{* * *} \\
\quad(-4.44)\end{array}$ \\
\hline Constant & $\begin{array}{l}3.093^{*} \\
(2.44)\end{array}$ & $\begin{array}{l}\text { Precipitation, growing } \\
\text { season*Batbaice }^{2}\end{array}$ & $\begin{array}{c}-0.0060^{* * * *} \\
(-4.61)\end{array}$ \\
\hline$N$ & 715 & & \\
\hline
\end{tabular}

Robust $t$ statistics are in parentheses; significance levels are $* p<0.05, * * p<0.01$, and ${ }^{* * *} p<0.00$. ${ }^{\text {a }}$ Winter season: Dec. 1 to Feb. 28 ; growing season: Mar. 1 to Sep. 15; harvest season: Sep. 16 to Oct. 31. ${ }^{\mathrm{b}}$ Batbaice: Beerenauslese-Trockenbeerenauslese-Eiswein.

significantly different from those on the lowest category, Qualitätswein (Qba). This result may be surprising at first, but one may consider the fact that the aggregation Batbaice includes Eiswein, a wine category that does not benefit from a warm growing season. Eiswein is made from frozen grapes, and German wine law stipulates that the congelation of at least $-7^{\circ} \mathrm{C}$ must take place on the vine, which is not attained every year. This makes the production of Eiswein risky, and only inferior vineyards are devoted to it.

The GLM results also suggest an increasingly deteriorating effect of the growing season's precipitation on the quality shares, especially within higher-quality brackets (Table 4).

Overall, the results of the SUR and the GLM approaches convey a significantly positive impact of average temperatures and average minimum temperatures during the whole season on the output shares of wine in higher-quality categories, while precipitation during the growing season reduces this share significantly.

\section{Conclusion}

The analysis suggests that the hypothesis that beneficial weather-here indicated by rising average temperatures during the growing season - will increase total wine production holds true, while additional soil-freezing days seem to have an adverse effect 
on total wine production. Regarding the shares of wine in higher-quality categories, rising average and rising minimum temperatures have a significantly positive impact on wine in higher-quality brackets.

The European Environmental Agency (2016) projects annual average land temperature over Europe to increase over the rest of this century by around $2.4^{\circ} \mathrm{C}$ to $4.1^{\circ} \mathrm{C}$; this predicted rise in temperatures may lead to higher total outputs and higher shares of outputs of wines in higher-quality categories in Germany. Expected drier growing seasons (Lübbecke, 2010) as well as the decrease in the number of growing-season freezing days may add to this effect.

\section{References}

Alston, J. M., Fuller, K. B., Lapsley, J. T., and Soleas, G. (2011). Too much of a good thing? Causes and consequences of increases in sugar content of California wine grapes. Journal of Wine Economics, 6(2), 135-159.

Alston, J. M., Fuller, K. B., Lapsley, J. T., Soleas, G., and Tumber, K. P. (2015). Splendide mendax: False label claims about high and rising alcohol content of wine. Journal of Wine Economics, 10(3), 275-313.

Ashenfelter, O. (2008). Predicting the quality and prices of Bordeaux wine. Economic Journal, 188, F174-F184.

Ashenfelter, O., and Storchmann, K. (2010). Using a hedonic model of solar radiation to assess the economic effect of climate change. The case of Mosel valley vineyards. Review of Economics and Statistics, 92(2), 333-349.

Ashenfelter, O., and Storchmann, K. (2016). Climate change and wine: A review of the economic implications. Journal of Wine Economics, 11(1), 105-138.

European Environmental Agency. (2016). Global and European temperatures. Available at http://www.eea.europa.eu/data-and-maps/indicators/global-and-european-temperature-1/ assessment.

Fecke, B. (2014). Klimawandel stellt Winzer vor neue Probleme. Deutschlandfunk, 03.11.2014. Available at http://www.deutschlandfunk.de/weinanbau-klimawandel-stelltwinzer-vor-neue-probleme.697.de.html?dram:article_id=302145 (accessed on November 8, 2017).

German Wine Institute. (2003-2016). Deutsche Weinstatistik 2003/2004-2015/2016. Available at http://www.deutscheweine.de/service/downloads (accessed November 8, 2017).

Haeger, J. W., and Storchmann, K. (2006). Prices of American pinot noir wines: Climate, craftsmanship, critics. Journal of Agricultural Economics, 35(1), 67-78.

Hoyos, R., and Sarafidis, V. (2006). Testing for cross-sectional dependence in panel-data models. Stata Journal, 6(4), 482-496.

Kriener, M., and Mortsiefer, H. (2017). Weinproduktion sinkt auf 50-Jahres-Tief. Tagesspiegel, 24.10.2017. Available at http://www.tagesspiegel.de/wirtschaft/ernte-2017weinproduktion-sinkt-auf-50-jahres-tief/20497304.html.

Lecocq, S., and Visser, M. (2006). Spatial variations in weather conditions and wine prices in Bordeaux. Journal of Wine Economics, 1(2), 114-124.

Leeuwen, C., and Darriet, P. (2016). The impact of climate change on viticulture and wine quality. Journal of Wine Economics, 11(1), 150-167. 
Lübbecke, A. (2010). Klimawandel verhilft deutschem Wein zur Vollreife. Die Welt. Available at http://www.welt.de/wissenschaft/umwelt/article8796031/Klimawandel-verhilft-deutschemWein-zur-Vollreife.html (accessed on November 8, 2017).

Mira de Orduña, R. (2010). Climate change associated effects on grape and wine quality and production. Food Research International, 43(7), 1844-1855.

Oczkowski, E. (1994). A hedonic price function for Australian premium table wine. Australian Journal of Agricultural Economics, 38(1), 93-110.

Oczkowski, E. (2016). The effect of weather on wine quality and prices. An Australian spatial analysis. Journal of Wine Economics, 11(1), 48-65.

Sarafidis, V., and Wansbeek, T. (2012). Cross-sectional dependence in panel data analysis. Econometric Reviews, 31(5), 483-531.

Storchmann, K. (2005). English weather and Rhine wine quality: An ordered probit model. Journal of Wine Research, 16(2), 105-120.

UCLA, Statistical Consulting Group. (2017). How does one do a regression when the dependent variable is a proportion? Available at https://stats.idre.ucla.edu/stata/faq/how-doesone-do-regression-when-the-dependent-variable-is-a-proportion/ (accessed on November $6,2017)$.

Zellner, A. (1962). An efficient method of estimating seemingly unrelated regressions and tests for aggregation bias. Journal of the American Statistical Association, 57(298), 348-368. 